\title{
Swiss Political Parties: Between Persistence and Change
}

\section{ANDREAS LADNER}

From a comparative perspective, two aspects of the Swiss party system are particularly salient: the large number of parties and the relative stability of the distribution of power. Apart from social and cultural cleavages, the electoral system (PR), the competitiveness encouraged by the federal state and direct democracy can be seen as responsible for party proliferation in Switzerland. ${ }^{1}$ Political stability stems from the integrative force of consociationalism, which has its roots in the small size of the country, its political culture, and the system of direct democracy. In Switzerland the most important parties are continuously represented in government, and there is no change of power between the parties in government and the parties in opposition. The composition of the national, as well as almost all cantonal, governments quite often remains unchanged over a long period. Since 1959, the national government, for example, has consisted of two members of the Radical Democrats (FDP), the Christian Democrats (CVP) and the Social Democrats (SPS), and one of the Swiss People's Party (SVP). This composition is commonly referred to as the 'magic formula'.

The combination of a large number of parties and political stability is not without interest, since the literature on party research, influenced by the experience of the Weimar Republic, the French Fourth Republic, and postwar Italy, for long treated multi-party systems as inherently unstable compared with two-party systems, such as that of Great Britain. ${ }^{2}$

However, in the last few years the Swiss party system seems to have become less stable. The 1995 and 1999 national elections brought about remarkable shifts in voting. The question is: will Swiss politics enter a period of instability and will there be serious changes in the party system? To grasp the importance of these changes, analyses restricted to the national level might be too narrow. It is a commonly accepted characteristic of the 
Swiss party system that the subnational level is of great importance. The federal structure of the political system has not only hampered the creation of powerful centralised national parties and led to much stronger cantonal parties, ${ }^{3}$ it has also brought about distinctive party systems with different power configurations. Moreover, cantonal organisations of the same party are not always backed by the same segments of the population. The Swiss party system has thus to be regarded as one composed of 26 different party systems.

Thus, it is of crucial importance to know to what extent changes on the national level correspond with cantonal trends and whether cantonal trends precede national trends or vice versa. The different size of the voting districts (cantons) for national elections, with a number of districts in which more than 30 per cent of the vote is needed to gain a seat, not only favours bigger parties, but might lead to an underestimation of the changes occurring. Yet the nationalisation of politics ${ }^{4}$ might have led to the disappearance of the differences between cantonal and national party systems.

The Number of Parties: A Decrease on National Level and an Increase in some of the Cantons

In the 1999 national elections, members of 14 parties were elected to the National Council (Nationalrat). This high number, of course, reveals only part of the story. Not all of these parties are of equal importance, some of them exist only in one or a few of the 26 cantons, whereas others are represented in all cantons. Basically, two groups of parties can be distinguished: the four governmental parties FDP, CVP, SVP and SP and the smaller parties like GPS, LPS, EVP, SD and others. ${ }^{5}$ On a national level, the former group shares between 70 and 90 per cent of the vote, while the latter parties, individually, hardly gained more than five per cent of the vote. ${ }^{6}$

To appreciate the degree of fragmentation of the Swiss party system and its cantonal party systems in a comparative perspective, we need to know more about the parties elected. Giovanni Sartori's ${ }^{7}$ criteria for the parties that 'count' are not very helpful, because the Swiss system of direct democracy allows even smaller parties to play a relatively important role and some are quite dominant in some of the cantons. ${ }^{8}$ Thus, the assessment of the parties that count on national level and in the 26 cantons remains a rather hazardous and arbitrary task. Instead, comparative studies frequently refer to the effective number of parties, a measure introduced by Markku Laasko and Rein Taggepera ${ }^{9}$ based on the Rae Fragmentation Index. The effective number of parties index has the advantage that it not only takes 
into account the number of parties, but also their size. Furthermore, it can easily be computed from electoral statistics.

After the 1999 national elections, the effective number of parties on national level amounted to 5.9 parties. Figure 1 reveals that this number is considerably higher than it used to be before the 1960s, but is remarkably lower than in the late 1980s and early 1990s. Responsible for the two peaks since 1945 were - to the detriment of the four governmental parties - the right-wing anti-immigration parties SD (formerly NA) and Republicans in 1971, and the Green Party (GPS) and its counterpart, the anti-ecologist Automobile Party (FPS), in 1991. Nevertheless, the effective number of parties in Switzerland can be considered as high compared with other countries. In the last four-year period of the twentieth century, only Belgium, Italy and France had a higher effective number of parties; the European mean is much lower and shows astonishing stability until the 1980s followed by a slight increase.

At first glance, the cantonal party systems do not reveal a similarly dynamic pattern. The mean is considerably lower than in the figures on a national level and the general trend only shows a slight and steady increase, the short-term ups and downs can hardly be distinguished. This is not surprising since average numbers have the inconvenience that trends are levelled out.

FIGURE 1

THE EFFECTIVE NUMBER OF PARTIES

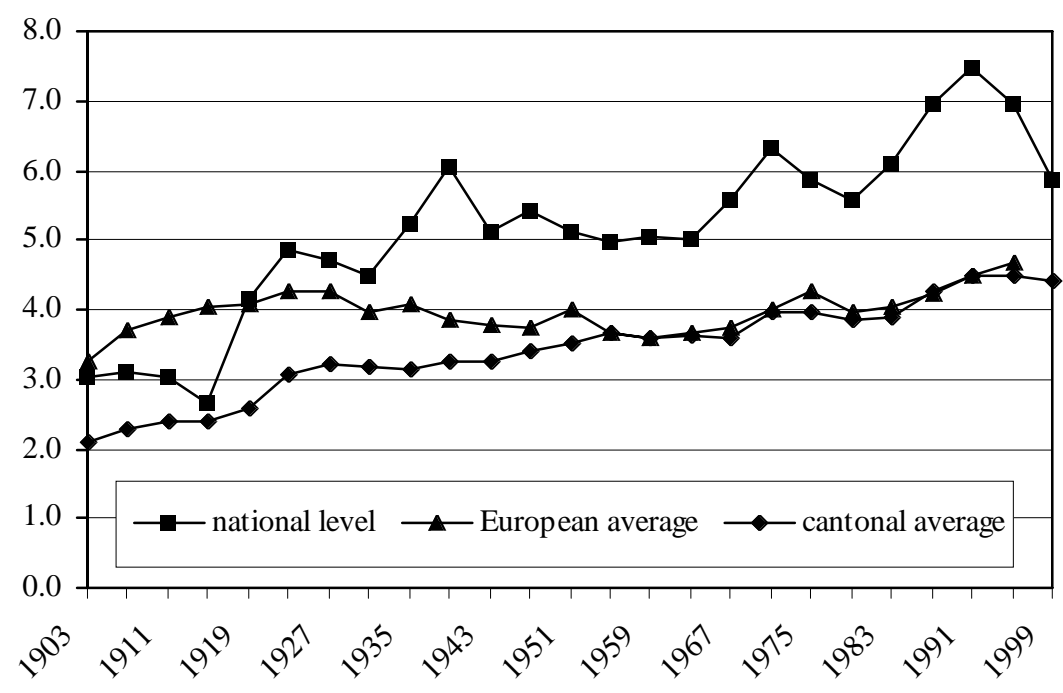


FIGURE 2

EFFECTIVE NUMBER OF PARTIES IN DIFFERENT GROUPS OF CANTONS

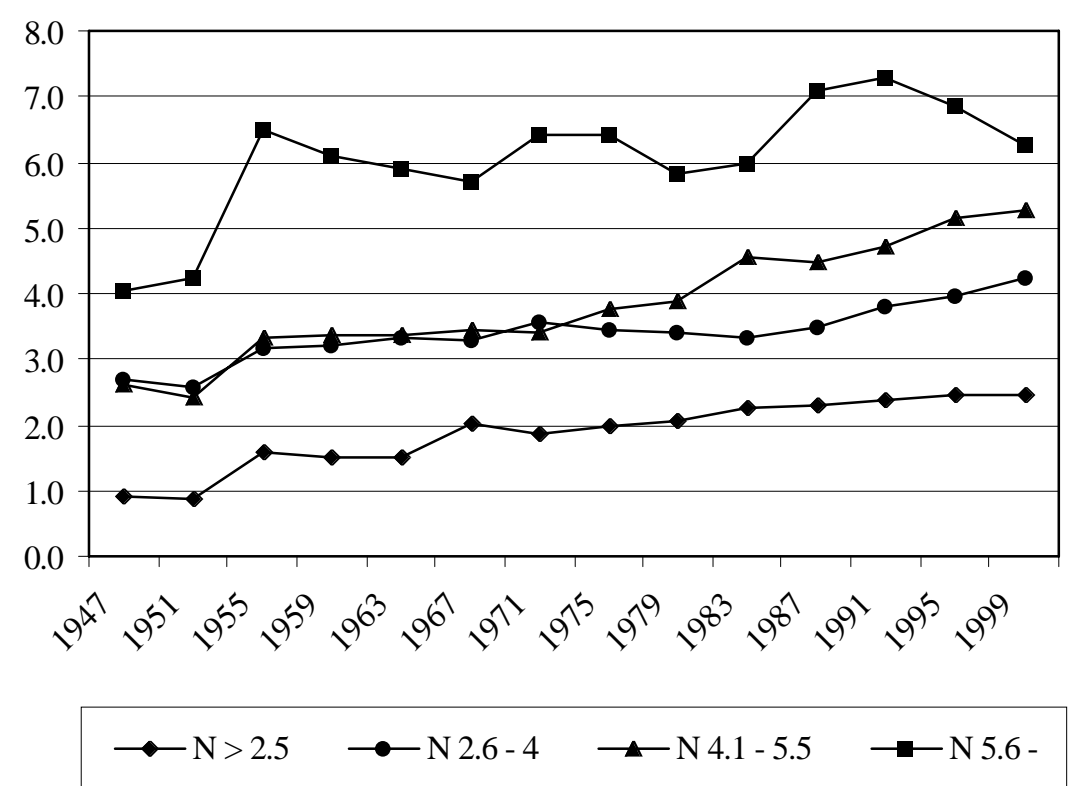

Notes: $\mathrm{N}=$ average effective number of parties in the two electoral periods $1980-83$ and 1984-87.

<2.5: UR, OW, NW, VS; 2.6 - 4: LU, SZ, GL, ZG, FR, SO, SG, TI, VD, NE; 4.1 - 5.5: BE, SH, GR, AG, TG, JU; 5.6 -: ZH, BL, BS, GE.

Figure 2 shows the trends for four different groups of cantons, built according to the average effective number of parties they had in the 1980s. The cantons' effective numbers of parties at that time were between two and well over 7.9. Figure 2 reveals significantly that the downward trend in the 1990s on national level also holds for cantons with a high number of parties in the $1980 \mathrm{~s}^{10}$ The average of those four cantons (ZH, BL, BS and GE) which had more than 5.6 parties in the 1980s clearly decreases. For the cantons with fewer parties the average number increases: only slightly for those with less than 2.5 parties in the 1980s (UR, OW, NW, VS), considerably for those with between 2.6 and 4 parties (LU, SZ, GL, ZG, FR, SO, SG, TI, VD, NE) and for those with between 4.1 and 5.5 parties (BE, SH, GR, AG, TG and JU).

Are there any characteristic differences between cantons with a different number of parties and different trends in the 1990s? It is - apart from a few 
exceptions (GE, JU) - in the confessionally mixed or dominantly Protestant cantons that the effective number of parties was high in the 1980s and decreased in the 1990s. Especially salient was the decrease in the cantons with important cities and universities like Zurich, Geneva and Basel. Cantons with a low, but slightly increasing, number of parties were - apart from GL, VD, NE - dominantly Catholic and of larger size. Almost no increase was found in smaller, off-centre, Catholic cantons dominated by the CVP. ${ }^{11}$

As far as the number of parties is concerned, there are thus quite important differences between the cantonal party systems and the national party system as it is depicted by national election results. The trend on the national level does not necessarily match all trends on the cantonal level. Nevertheless, the differences seem to disappear. The cantonal party systems become more alike, converging towards a medium effective number of parties between four and five, and the national party system is reduced to well below six parties. If there is anything like a nationalisation of cantonal politics, this should, in the long run, lead to similar party systems on all levels.

\section{Volatility: Increase on a Low Level}

Given the multitude of parties, the stability of the parties' vote and seat shares during the twentieth century is remarkable. This reveals, for example, the elasticity of voting strength, measured by the percentage difference between the largest and the least share of the vote which a party obtained at elections over a given time period..$^{12}$ The best and worst results of SVP and CVP since the introduction of the proportional system in 1919 and up to the 1995 election differ by less than seven per cent. For the FDP, this difference is less than nine per cent; only the SP passes the ten per cent mark. And the mean change, that is the average change in the percentage of the vote obtained by a party between each pair of elections during a period, ${ }^{13}$ is very small. For the four governmental parties, it is 0.9 for the FDP, 0.7 for CVP, 1.3 for SVP and 1.4 for SP. All these parties would - according to the study by Maria Maguire ${ }^{14}$ - belong to the group of parties with very little change.

Measured at the level of the whole Swiss party system, the volatility, that is half of the total change in percentage of votes between parties within a party system, ${ }^{15}$ is also rather low compared with other countries. The average aggregated volatility in the time between 1919 and 1999 is five per cent. However, in the 1990s this varied. The average on national level in the three elections in the 1990s was up to 7.8 per cent, whereas in the years 
before it was much lower (see Figure 3). Only in 1971 and before and after World War II did Switzerland's party system witness similar volatility. Especially salient is the low volatility in the 1950s and early 1960s, when the magic formula was established in 1959.

The comparison with the developments in the cantonal party systems reveals that there is a certain similarity between the two curves, but it cannot be determined on which level new tendencies come out first. Again the differences between the cantons are considerable. In the last electoral period of the twentieth century, cantons like ZH, LU, OW, BS, SH and GE showed aggregated volatility of over ten per cent. In cantons like SZ, NW, SG, GR, TI and VS volatility was below four per cent.

The 24 cantonal party systems ${ }^{16}$ offer a quite unique opportunity to test the relation between the number of parties and the stability of a party system under almost laboratory-like conditions. Figure 4 reveals that cantons with a higher number of parties in the 1990s generally also have higher volatility. The correlation between the two variables is significant. The term 'political stability' has, of course, to be used cautiously. It can only be shown that the more parties there are, the more election results tend to be subject to change. Nothing can be said about the distribution of power and the stability of policies.

FIGURE 3

VOLATILITY

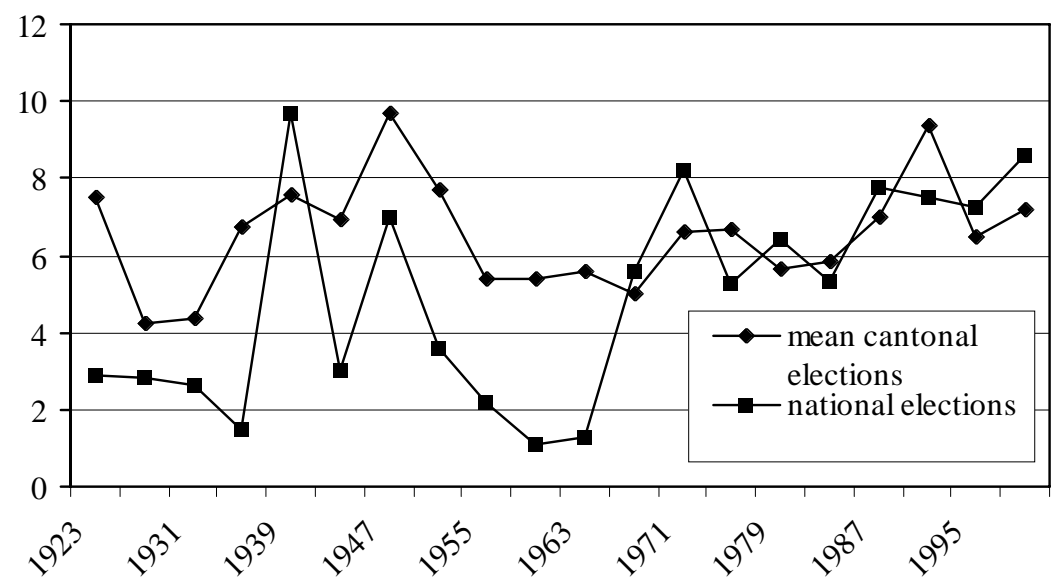

Note: $\mathrm{y}=$ per cent 
FIGURE 4

EFFECTIVE NUMBER OF PARTIES (1990s) AND VOLATILITY (1990s)

IN 24 SWISS CANTONS

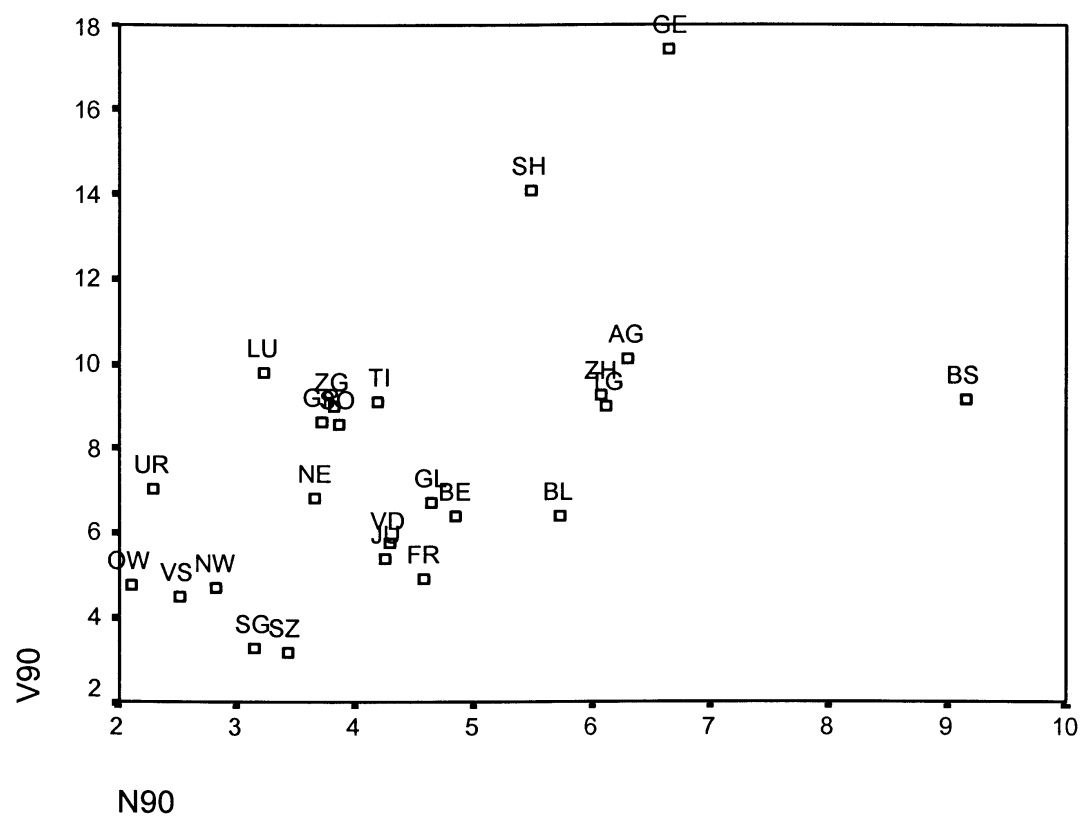

Note: Pearson corr: .548, sig.: .01; V90 and N90: average volatility and average effective number of parties in the three electoral periods 1988-91, 1992-95 and 1996-99.

Failure and Success of the Different Parties: The Ascent of the Swiss People's Party

The effective number of parties and aggregate volatility mirror quite accurately the changes in the Swiss party system in the 1990s, they remain, however, on an abstract level. The next step is to have a closer look at the most important parties.

The success of the Swiss People's Party (SVP) in the 1990s is probably the most striking in the whole electoral history of the Swiss party system (see Figure 5). Not more than 25 years ago, the SVP fell below ten per cent and was almost doomed to disappear. It was only with the 1991 elections that this downward trend stopped and, in the elections of 1995, the party reached an unexpected 15 per cent. The 1999 elections finally marked a real breakthrough. The SVP became the strongest party with 22.5 per cent of the 
vote (+ 7.6). It is the first time since the National Council (Nationalrat) was first elected by means of proportional representation in 1919 that such an important shift has occurred. In addition to its traditional strongholds, the party not only consolidated its position in cantons like LU, ZG, SO, AR, SG, where it entered the national political arena in the 1995 elections, but also gained votes in 'new' cantons like BS, AI, VS, GE and JU. The success of this formerly agrarian party is due to profound transformation, as it was forced to reorient itself because of the shrinking of its traditional membership base of farmers and merchants. It now favours a free-market economy and a reduction in state expenditure; however, its agricultural policy still tolerates massive state intervention. Domestically, the party puts great emphasis on the maintenance of law and order, is strongly antiimmigration, and in foreign policy it vehemently opposes Switzerland's accession to supranational organisations (EU, UNO).

The trends for the other parties are less spectacular, but not less significant. The Radical Party (FDP), which advocates a liberal economic order with a business-friendly framework, has been the biggest and most important party for a long time and has been considered as the founding party of the Swiss nation state; it had already experienced a decline following the introduction of the proportional system in 1919 and lasting until 1939. After a period of ups and downs, a new downward trend started after the elections of 1983 . With the 1999 elections, the FDP for the first time lost its leading position among the three bourgeois parties.

\section{FIGURE 5}

ELECTORAL PERFORMANCE OF THE FOUR GOVERNMENTAL PARTIES IN NATIONAL COUNCIL ELECTIONS

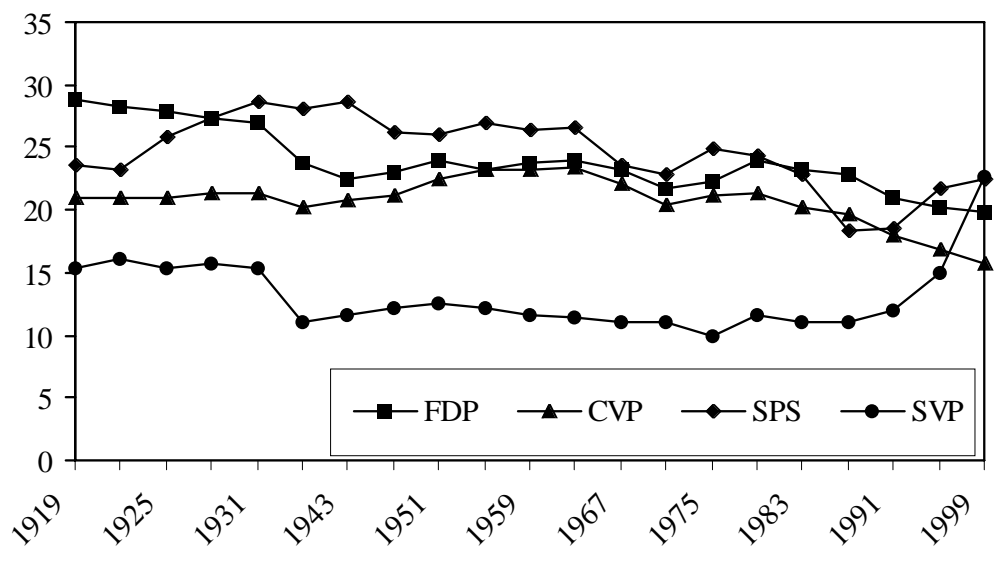


The Christian Democratic Party (CVP) professes the Christian social doctrine and advocates the establishment of a social market economy, allowing for state interventions in order to protect workers, craftsmen and agriculture. On ethical and moral issues, it adopts a conservative stance, and it attributes great importance to family values. The figures for the CVP show that there has been a marked drop since 1963, and more particularly since 1979. It is still suffering from the ongoing process of secularisation and is now the smallest of the four governmental parties.

Finally, the Social Democratic Party (SPS) stands for the protection of the socially weak and the environment. It is an advocate of subsidy programmes, active state intervention in the economy, and the creation of a strong social safety net that does not push the socially disadvantaged into the role of supplicants. The history of the Social Democrats is more agitated, which is partly due to the temporary success of other, more extreme left-wing and green parties. The SP fell below the 25 per cent mark before and immediately after the events of 1968, and below 20 per cent in the 1987 and 1991 elections, which were strongly influenced by environmental issues. In 1995 it recovered and even became the second strongest party in 1999 with little more than 22 per cent.

The smaller parties lost much of their attraction towards the end of the twentieth century. The LdU disappeared, the FPS is about to do the same, the Greens have been able to hold their share of the votes, but suffered a reduction of 1.1 per cent in the 1995 elections. The SD also suffered quite important losses and the LPS minor ones, whereas the shares of EVP and EDU remained unchanged. Thus, with the 1999 elections the four governmental parties again controlled more than 80 per cent of the vote; however, the clear winners in the last decade of the twentieth century were the parties at the poles of the left-right dimension, the SVP and the SP.

The 1999 elections also brought a new situation in regard to the composition of the national government. The success of the SVP was followed by the claim for a second seat in the Federal Council, which was refused by the other parties at the end of 1999 in the re-election of the government following the election of the National Council. However, the magic formula has lost much of its enchantment and changes are more probable than ever.

In the light of these developments, the question is whether the Swiss party system has lost its famous stability. There is obviously a reduction in the number of parties and an increase in volatility. This is not completely new. Long term analyses reveal that the Swiss party system has had ups and downs as far as volatility and the number of parties are concerned. But 
altogether the Swiss party system seems - apart from a few exceptions - to be moving towards a four-party system with the four governmental parties being even more dominant. At a first glance this supports Seymour Lipset and Stein Rokkan's thesis of the frozen party systems. ${ }^{17}$ Their cleavage theory explains the emergence of the four parties quite well. However, the success of the SVP also threatens the very essence of the Swiss four-party coalition. Especially the two parties in the middle, FDP and CVP, are under enormous pressure and a reorganisation of the Swiss party system has become more probable than ever. And finally, the Lipset-Rokkan thesis only holds as long as the four parties still represent the same cleavages and stand for the same political ideologies. It is on the level of the parties and their organisations that the answer to this question of stability is to be found.

\section{WEAK PARTY ORGANISATIONS, DEALIGNMENT AND REORIENTATION}

The electoral records of the parties tell only part of the story. Without leaving any traces in electoral statistics, changes might take place within the parties, for example, in regard to the parties' organisations, their relationship to their adherents and members and their political orientation. It is, therefore, time to have a closer look at the parties themselves.

Swiss political parties are considered to be weak. ${ }^{18}$ Most analysts point to the parties' handicap vis-à-vis interest groups and social movements. Further signs of their weakness are connected with the internal organisation of the parties, for instance, the small and largely voluntary party apparatus, limited financial resources, and the lack of centralisation and internal homogeneity. ${ }^{19}$ These characteristics of the political parties can be largely explained with reference to special features of the Swiss political system.

Switzerland is a small country with a strong social and cultural diversity. Different language areas, confessions and degrees of urbanisation provide for all sorts of cleavages. Together with the very federalistic structure of the Swiss political system and the predominantly autonomous municipalities, the Swiss parties are, despite their large number, somewhat heterogeneous and stratarchically organised. Altogether there are about 180 cantonal parties and roughly 5,000 local parties..$^{20}$ As a consequence, the national parties have to make great efforts to solve their integration and coordination problems. At the same time, however, a decentralised party structure enhances flexibility in dealing with local and regional particularities $^{21}$ and offers more opportunities for voter identification. In 
cases where the cantonal party deviates from the national party, the party members can choose, according to their own preferences, which party to identify with more.

Even though the system of direct democracy contributed early on to the formation of the political parties in Switzerland, ${ }^{22}$ most analysts argue that, at the end of the twentieth century, direct democracy weakens the position of the parties. ${ }^{23}$ During voting campaigns, the financially strong interest groups and the social movements, which are easy to mobilise, far outpace the political parties. In addition, given the possibility of correcting unfavourable decisions by the popular vote, the elections themselves are relatively unimportant. Recent studies have shown, however, that in those cantons where initiatives and referenda are frequent, the parties tend to be better organised. ${ }^{24}$ Either a large number of direct democratic ballots tends to force the parties to engage in continuous political activism, and this might lead them to professionalise their internal organisation, or having sufficient organisational capacity they tend to resort more often to direct-democratic instruments.

For small and heterogeneous states, a conflict regulation pattern based on consensus and power-sharing seems to be more appropriate. ${ }^{25}$ The Swiss system of consensus democracy (consociationalism) allows the most important parties to participate in government. This provides much more integration than majoritarian systems with a strong division between the parties in government and parties in the opposition. In a consensus democracy, political problems are solved quietly. Representatives of the main interest groups take part in the decision-making process at an early stage and help to find a compromise to solve political problems. Such a conflict regulation pattern guarantees political stability, but blurs the borders between political interest groups and government actors. It remains unclear whose interests prevail in putting together a proposal. ${ }^{26}$ Political parties tend to lose the possibility of showing their constituents a distinctive political profile.

Finally, the Milizsystem ${ }^{27}$ which is in part a consequence of the small size of the country, but which is also considered to be an element of Swiss political culture, weakens the position of the parties. Even though the Milizsystem has some advantages in that it favours the combination of roles across the social and political sub-systems, ${ }^{28}$ it also implies that most political work is done by amateur politicians in a largely unprofessional manner. Finally, since the parties are able to offer their members only unpaid positions, this does not significantly enhance the attractiveness of the parties. 
There seems to be a broad consensus among various authors ${ }^{29}$ that political parties have passed through different stages of development during the twentieth century. ${ }^{30}$ Three forms of political party are usually distinguished. Until about 1920, the parties were mainly cadre or elite parties. With the consolidation of the Western democracies between 1920 and 1960, mass-membership parties emerged. Since 1960, the parties have become dissociated from their membership base and turned into Otto Kirchheimer's catch-all parties ${ }^{31}$ or into Angelo Panebianco's professional electoral parties. ${ }^{32}$ The latter two are no longer committed to 'grand ideologies' or to a particular segment of the population, but seek primarily to increase votes and seats. Richard Katz and Peter Mair add to these different developmental stages a further party type, the cartel party, which has emerged since $1970 .^{33}$ This new form of party has moved closer to, and is strongly subsidised by, the state.

The question is, of course, whether Swiss parties follow these lines of party development. Especially in the case of the catch-all party and the professional electoral party, and to a lesser extent for the cartel party, the weakened link to their traditional basis would question Lipset and Rokkan's frozen party system thesis. ${ }^{34}$ If only the names of the traditional parties survive, and they no longer represent the cleavage responsible for their emergence in terms of socio-structural basis and political orientation, the party system has changed and can no longer be considered as frozen.

Unfortunately, for most of the ideal types of party organisation, clear concepts of operationalisation are missing. Therefore, we shall concentrate on a few party characteristics, describing some features of the ideal types, such as professionalisation and financial resources of party organisations, party ties, membership figures and composition, the balance of power within the parties and the political orientation.

\section{Professionalisation: A Slight Increase on a Low Level}

In the mid-1970s, the parties of the medium-sized and larger cantons began to staff their secretariats with full-time employees. ${ }^{35}$ A survey conducted by the author in 1996/97 shows that the cantonal parties of the four governmental parties had 74 full-time positions in total. Added to the 45 positions of the national party organisations, this amounts to a total of nearly 120 full-time posts. Henry Kerr reports for the 1970 s, on the basis of personal interviews with party officials, a total of 87.5 full-time staff members at cantonal and national level together. ${ }^{36}$ Since the middle of the 1970s, the number of full-time employees has thus increased by 40 per cent at the best. Compared to developments in other countries, ${ }^{37}$ the 
increase of professionalisation in Switzerland is below average. Only Great Britain and the Netherlands have lower rates of increase, but in absolute terms these countries have a generally higher level of professionalisation. Moreover, in Switzerland, full-time employees are typically engaged in the administrative apparatus of the party, and therefore the actual level of professionalisation of the party's purely political activities is probably even lower. According to information provided by the parties themselves, about 72 per cent of the cantonal parties have become more professional in their administrative work, and 60 per cent in their programmatic and substantive activities, during the last ten years. ${ }^{38}$ It is noteworthy that especially the two most successful parties, the SP and the SVP, claim to work more professionally with regard to substantive issues.

Nevertheless, the conclusion reached by Hans Peter Fagagnini in the mid-1970s that the party organisations in Switzerland are based on the Milizsystem $^{39}$ is still valid today: the number of individuals who deal professionally with politics remains very small. Professional politicians are to be found mainly among representatives of interest groups and other persons who deal with questions that lie at the basis of political decisions. These are usually lobbyists or parliamentarians. ${ }^{40}$ The party organisations themselves employ only a small number of politically versatile collaborators.

\section{Financial Resources: No State Funding and Increasing Difficulties}

In comparison with parties of other countries, the Swiss parties have only limited financial resources, both in absolute terms, as well as in terms of growth rates over recent years. Partly responsible for this is the almost total lack of state funding. On the national level there is only a modest contribution to the parliamentary groups of about 5.5 million Swiss francs. In 1975 the ordinary budget of the four governmental parties on national level was 2.5 million francs (FDP: 0.8 million; CVP: 0.8 million; SP: 0.7 million; SVP: 0.2 million). ${ }^{41}$ At the end of the 1980s, the total budget of the four governing parties amounted to 5.6 million francs (SP: 1.7 million; CVP: 1.6 million; FDP: 1.4 million; SVP: 0.9 million). ${ }^{42}$ In 1999 , the four governing parties reported a total budget (without election costs) of 9.4 million francs (FDP: 2.6 million; CVP: 2.3 million; SP: 3.1 million; SVP: 1.4 million). Compared to most of the other countries the budgets of the Swiss parties are very small. And even the increase in recent years is hardly impressive when we consider the average rate of inflation. In the last three decades the four parties have in real terms roughly doubled their budget. The ordinary budget of all four governmental parties together on a national 
level is, for instance, considerably lower than the sum an organisation like Greenpeace receives in donations.

The fact that the Social Democrats have the largest budget on national level is striking. This is due to the fact that these figures do not account for all 'costs'. Contributions to electoral or voting campaigns, to a large extent, do not show up in the 'operative budgets' of the parties on the right. If these contributions could be taken into account, it could probably be shown that in reality the bourgeois parties, because of their connections with financially strong business circles, have more funds at their disposal.

The national parties' lack of financial resources is a matter of constant concern. In the last 30 years, there have been different unsuccessful attempts to introduce a system of state financing. In 1999, for the first time, all four governmental parties jointly tried to re-start the discussion. The financial situation of the cantonal parties is only slightly better. About 37 per cent of the 90 cantonal parties in our sample claim that they dispose of more money than in previous years. For 21 per cent the financial situation has not changed, whereas 42 per cent claim to be worse off. For FDP and CVP especially, the financial situation is not very comfortable; in both parties a majority of the cantonal sections claim to have comparatively less money than in earlier days. ${ }^{43}$ Both parties, as we have seen, are also fighting electoral problems.

\section{The Parties on the Ground: Dealignment and Realignment}

If there is a general pattern in the development of Western European party systems, it is the decline of party ties. However, there is great variation between countries, as well as between parties. ${ }^{44}$ Various surveys have shown that an ever-decreasing percentage of the population identifies closely with a political party. ${ }^{45}$ While in the early 1980 s, after a period of decline, about 50 per cent of the voters identified with one of the governing parties, this figure had dropped to one-third by $1995 .{ }^{46}$ In 1995 , more than half of the voters declared that they did not identify with any party. Concurrently, the number of floating voters has increased significantly, particularly between 1971 and $1987 . .^{47}$

In Switzerland, the principle of party membership developed relatively late and only partially, which is evidenced by the largely unsuccessful attempts of the FDP and the CVP to introduce this principle in the 1970s and 1990s in all cantonal and local branches. One possible explanation of this can be found in the party press, which until 1970 played a relatively important role. The parties organised themselves through the party press, 
that is, the readers represented members and followers, and, as a consequence, there was no need to develop clear criteria for membership and to establish organisational structures for such a task..$^{48}$

In 1963-67, according to Erich Gruner's estimates, 38 per cent of active voters were party members. In his view, the introduction of female suffrage reduced this number by half. In the 1970s, it amounted to 11 per cent of the eligible voters, which corresponds to approximately 390,000 party members. At the time, Gruner considered the Swiss parties' level of organisation to be relatively high by international comparison. ${ }^{49}$ According to indications given by the parties themselves, they had approximately 400,000 members in the mid-1990s, just as in Gruner's time. If we take into account the fact that during these 20 years the number of voters has increased by 900,000 , this implies that the percentage of party members has declined, a development which is confirmed by recent surveys. According to the studies by Longchamp between 1983 and 1994, the share of party members among the eligible voters declined from 18 to 12 per cent. ${ }^{50}$

The use of a more restrictive concept of membership, which eliminates those entries that (due to the lack of the principle of membership) were based on the more encompassing notion of 'followers', lowers the percentage of party members even further to seven per cent of the voters. From this perspective, the Swiss parties had only about 300,000 members in 1997. In international comparison, Switzerland still occupies a leading position in the middle field; in Germany, Holland, England and France, the parties have considerably fewer, in Austria considerably more members. ${ }^{51}$

As long as parties, as in the Swiss case, do not have central membership files, it is very difficult to establish trends in membership figures over time. In Switzerland, only the Social Democrats have the possibility of showing a plausible (negative) trend in their membership figures, whereas the other parties depend at the very best on estimations. About 40 per cent of the cantonal sections of the four governmental parties claim to have increased their membership figures in recent years, only about 24 per cent admit that they have fewer members. ${ }^{52}$ If we take into account the size of the parties (weighted percentages), we get a more accurate picture of the total trend. In this perspective, a downward trend comes out clearly, since it is mainly the small and newer cantonal parties which pretend to gain members, whereas the more important bigger parties have declining figures. But even here, the result is probably too positive for the parties. For example, in the case of the Social Democrats, which experienced according to their official statistics a 
clear loss in recent decades, the balance turns out to be even. It is thus very likely that party officials tend to put their membership figures in too favourable a light. Anyway, the two parties suffering most from a decrease of their membership figures are FDP and CVP.

In regard to the members and voters of the different parties, most striking is the shift in the social basis of the Social Democrats and the Swiss People's Party. The Social Democrats have lost a part of their traditional membership to the Swiss People's Party. Yet they have gained a considerable number of better educated people earning higher salaries. In 1975 only seven per cent of their voters had an university degree, ${ }^{53}$ whereas in 1999 the SP was, with 51 per cent, the party with the highest percentage of voters having a high level of education..$^{54}$ As far as income is concerned, the SP ranks with its percentage of well-off voters just behind the FDP and well ahead of CVP and SVP, while among the people from the highest income category the SP is the most popular party. The Swiss People's Party, in contrast, moved into the cities and into predominantly Catholic areas. In 1975 only eight per cent of their voters lived in urban areas, ${ }^{55}$ in 1999 it was 38 per cent. ${ }^{56}$ The percentage of Catholic voters increased according to the same source from 16.5 in 1975 to 34 in 1999.

\section{The Increasing Importance of Public Office and Central Office}

The balance of power between the different faces of party organisations ${ }^{57}$ and intra-party decision-making are other important features of political parties. Professional electoral parties and cartel parties have a strong bias towards the party leaders (party in central office) and the office-holders (party in public office). In the 1980s with the rise of green parties, grassroots democracy was very popular. In the 1990s this changed. Party leaders are not only constantly asked to present their position in the media without being able to consult their basis, but they also need enough room and competence for strategic behaviour. There has within the Swiss parties obviously been a shift towards more operative freedom for the party leaders. About two-thirds of the cantonal sections of the four governmental parties claim that leadership is more important than co-determination of the party members and almost half of them claim that there has been a shift in the priorities in this direction within the last few years (see Table 1). This change has been especially strong for the Social Democrats (SP) and the Christian Democrats (CVP). 


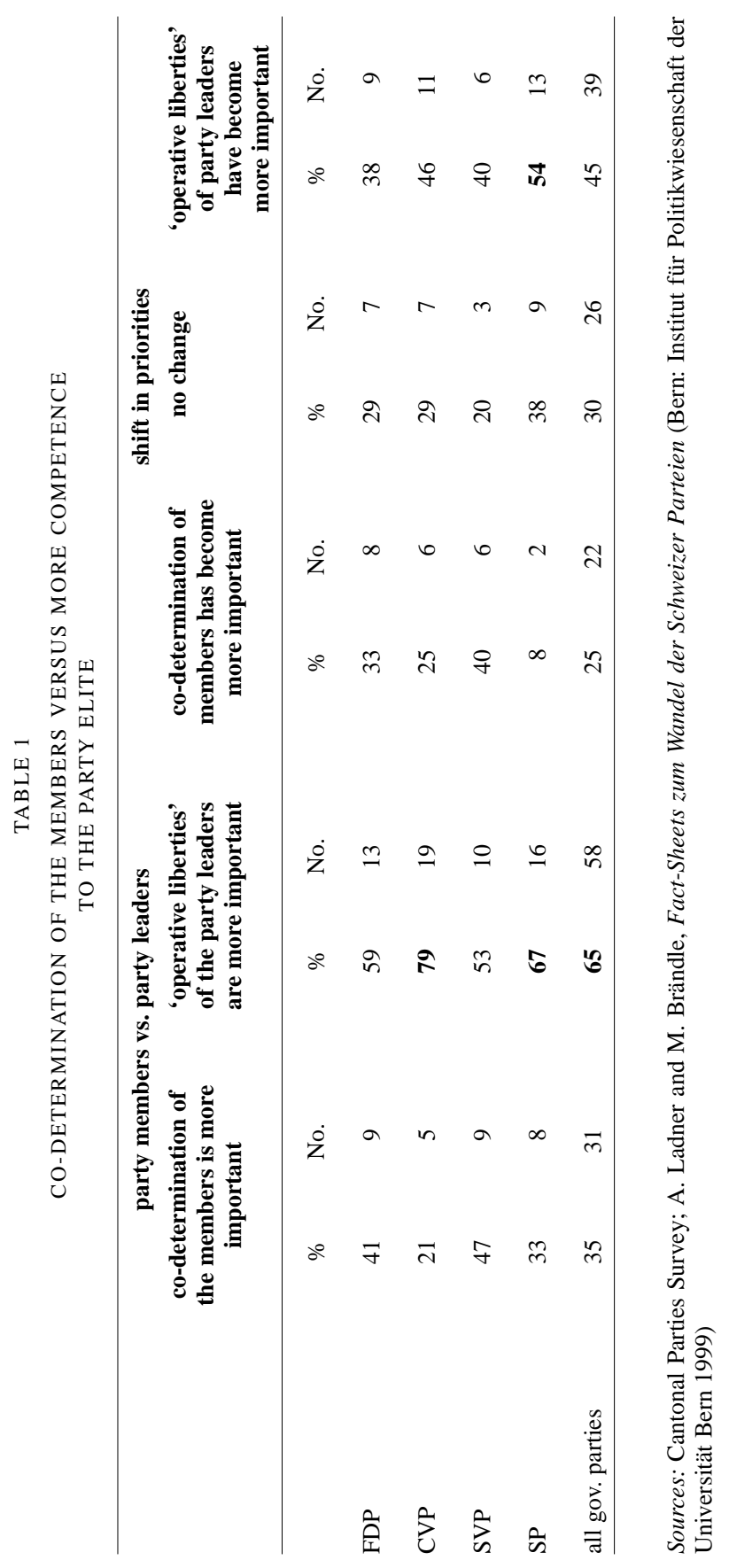




\section{Political Orientation: There are Still Differences}

In 1965, Otto Kirchheimer predicted a lessening in the importance of the parties' ideologies and a trend towards a two-party system with very few ideological differences between the two parties. ${ }^{58}$ Obviously his predictions were wrong. Switzerland still has a multi-party system and the differences between some of the parties have even increased. Especially salient is the shift of the successful Swiss People's Party. Older studies covering the 1970s place the SVP much more in the middle and even to the Left of FDP and CVP. ${ }^{59}$ More recent studies situate the Swiss People's Party clearly on the Right. ${ }^{60}$ Studies analysing the parties' electoral programmes ${ }^{61}$ reveal that the Swiss People's Party has clearly changed its political orientation to the Right as far as political issues are concerned. The Social Democrats on the other side have increased their Left orientation and consider themselves as one of the most leftist and ecological Social Democratic parties.

To sum up, despite many similarities in the development of the Swiss parties, it is impossible to discern a uniform pattern. The Swiss parties, especially if the cantonal parties are also taken into account, cover almost the entire spectrum of party types discussed in the literature. It is still possible to find cantonal-level parties that are best characterised as elite parties, especially in central Switzerland. Some parties, such as the SP, are clearly based on the principle of membership, while others - such as the former LdU or, at a lower level of organisation, the SD and the FPS - come close to the model of a electoral party. Finally, there is little evidence that the Swiss parties have moved closer to the state, a development which is typical of cartel parties. Especially salient here is the lack of public funding of the parties. Thanks to the Milizsystem, which even applies to the highest levels of the political system, politicians have been able to maintain a certain degree of independence. The system of concordance and the multiparty system seem to ensure that a considerable number of public sector positions are not allocated on the basis of party membership alone. However, given the high density of political offices in Switzerland, the parties have always had relatively easy access to political mandates.

\section{PERSISTENCE OR CHANGE?}

How can the Swiss party system and the Swiss parties be characterised at the end of the twentieth century in terms of persistence and change? At first glance, persistence seems to prevail. The four governmental parties control more votes than during the last 30 years and, in regard to their organisations, there have not been fundamental changes which would allow us to speak 
about a new party system, hardly comparable to the one in the 1960 s or even in the 1920s. Despite partial support for some of the characteristics, Swiss parties cannot be described as catch-all parties in the sense of Kirchheimer, ${ }^{62}$ nor as professional electoral parties in the sense of Panebianco, ${ }^{63}$ or cartel parties in the sense of Katz and Mair, ${ }^{64}$ which would mark a quite important difference from traditional parties on the basis of members and political ideologies.

However, the image of stability and persistence has to be questioned for three reasons. First, the Swiss parties, like parties in many other countries, ${ }^{65}$ lost support from party members. Party ties have weakened. The impressively good electoral results of the four large parties together are on less firm ground than they used to be. Secondly, the cleavages responsible for the emergence of the four parties are less dominant, some have partially disappeared and, what is even more striking, there has been a switch in the social basis of the different parties. Traditional working-class voters of the Social Democrats have changed to the right-wing Swiss People's Party and, with its most recent turn towards more neo-liberal policies, the Swiss People's Party has become more attractive for voters of the Radical Party. The Social Democrats, on the other hand, have become much more popular among well-educated people with relatively high salaries. Thus, we have the same parties, but their social bases and their political claims have changed. And, thirdly, the success of the Swiss Peoples' Party has made a reorganisation of the Swiss party system more likely than ever.

\section{NOTES}

1. W. Linder, Schweizerische Demokratie. Institutionen, Prozesse, Perspektiven (Bern: Haupt 1999), pp.81-8.

2. P. Mair, 'Introduction', in P. Mair (ed.), The West European Party System (Oxford: University Press 1990), pp.1-22 at 18 .

3. H.P. Fagagnini, 'Die Rolle der Parteien auf kantonaler Ebene', in Schweizerisches Jahrbuch für politische Wissenschaft (Bern: Haupt 1978), pp.75-94; S. Hug, 'La cohésion des partis fédéraux dans la phase référendaire', in Y. Papadopoulos (ed.), Elites politiques et peuple en Suisse. Analyse des votations fédérales: 1970-1987 (Lausanne: réalités sociales 1994), pp.85-112 at 86; L. Neidhart, 'Funktions- und Organisationsprobleme der schweizerischen Parteien', in Schweizerisches Jahrbuch für politische Wissenschaft (Bern: Haupt 1986), pp.17-43 at 41; D.-L. Seiler, 'Enjeux et partis politiques en Suisse', Pouvoirs, 43 (1987), pp. $115-38$ at 119 .

4. D. Caramani, 'The Nationalisation of Electoral Politics: A Conceptual Reconstruction and Review of the Literature', West European Politics 19/2 (1996), pp.205-24; K. Armingeon, 'Es gibt sie doch, die Schweizer Wahlen! Die Unterschiedlichkeit des Wahlverhaltens zwischen Kantonen im internationalen Vergleich', in H. Kriesi, W. Linder und U. Klöti (eds.), Schweizer Wahlen 1995. Ergebnisse der Wahlstudie Selects (Bern: Haupt 1998), pp.273-95.

5. GPS = Green Party, LPS = Liberal Party, EVP = Protestant People's Party, LdU = Independents' Party, SD = Swiss Democrats, formerly named National Action (NA), FPS = 
Freedom Party formerly named Motorists' or Automobile Party (AP), EDU = Federal Democratic Union, Lega = League of the Tessins, PdA = Workers' Party.

6. Remarkable exceptions are the LdU, which gained 9.1, 7.6 and 6.1 in the elections in 1967, 1971 and 1975 and the Green Party with 6.1 per cent in the 1991 elections.

7. G. Sartori, Parties and Party Systems. A Framework for Analysis, Vol. I (Cambridge University Press 1976).

8. For example the Lega in TI, PdA in VD and GE, and LPS in most of the French-speaking cantons and in BS.

9. M. Laakso and R. Taagepera, 'Effective Number of Parties. A Measure with Application to West Europe', Comparative Political Studies 12/1 (April 1979), pp.3-27.

10. Since the four groups are built according to their average effective number of parties they are not necessarily homogenous as far as their trends in the 1990s are concerned. The argument here is based on the trends for the average of each group.

11. The language cleavage is not of any direct influence since there are in fact no languagespecific parties. In linguistically mixed cantons like VS or FR some of the parties (CVP, FDP, SP) are organisationally divided into a German-speaking and a French-speaking party, in the electoral statistics, however, they do not appear separately.

12. R. Rose and D.W. Urwin, 'Persistence and Change in Western Party Systems, 1945-1969', in P. Mair (ed.), The West European Party System (Oxford: Oxford University Press 1990), pp.185-94, excerpted from 'Persistence and Change in Western Party Systems Since 1945', Political Studies 18/3 (1970), pp.287-319.

13. M. Maguire, 'Is There Still Persistence? Electoral Change in Western Europe, 1948-1979', in H. Daalder and P. Mair, Western European Party Systems (London: Sage 1983), p.78.

14. Ibid.

15. M. Pedersen, 'The Dynamics of European Party Systems: Changing Patterns of Electoral Volatility', European Journal of Political Research, 7 (1979), pp.1-26.

16. Due to electoral incompatibilities two (AI and AR) of the 26 Swiss cantons are not represented in the sample.

17. S.M. Lipset and S. Rokkan, 'Cleavages Structures, Party Systems and Voter Alignments: An Introduction', in S.M. Lipset and S. Rokkan (eds.), Party Systems and Voter Alignments (New York: Free Press 1967), pp.1-64.

18. R. Rhinow, 'Funktionen und Probleme der politischen Parteien in der Schweiz', recht 4 (1986), pp.105-119 at 105; C. Longchamp, Unterstützung von Bundesrat und Verwaltung. Wandlungen im Verhältnis von Bürgerschaft und Regierung in der Mitte der 90er Jahre als eine Herausforderung an eine offene Staatstätigkeit (Zürich: GfS-Forschungsinstitut und Bundeskanzlei und EJPD Bern 1994), p.25; I. Rickenbacher, Politische Kommunikation (Bern: Haupt 1995), p.13; H. Kriesi, Le système politique suisse (Paris: Economica 1995), p.131.

19. The lack of formal recognition by the state no longer holds, since the new Constitution of 18 April 1999, finally mentions political parties (Art. 137). In legal terms, the Swiss parties are organised as associations (Vereine), according to Articles 60-79 of the Civil Code (ZBG). Their statutes determine their purpose, their means, and their internal organisation.

20. A. Ladner, Politische Gemeinden, kommunale Parteien und lokale Politik. Eine empirische Untersuchung in den Gemeinden der Schweiz (Zürich: Seismo 1991); H. Geser et al., Die Schweizer Lokalparteien (Zürich: Seismo 1994); A. Ladner and M. Brändle, Fact-Sheets zum Wandel der Schweizer Parteien (Bern: Institut für Politikwissenschaft der Universität Bern 1999).

21. H. Kriesi, 'Perspektiven neuer Politik: Parteien und neue soziale Bewegungen', Schweizerisches Jahrbuch für politische Wissenschaft 1986 (Bern: Haupt 1986), pp.333-50 at 337.

22. E. Gruner, Die Parteien der Schweiz, 2. Auflage (Bern: Francke 1977), p.25.

23. E. Gruner, 'Parteien', in U. Klöti (ed.), Handbuch Politisches System der Schweiz, Band 2 (Bern: Haupt 1984), pp.135-62 at 150.

24. A. Ladner and M. Brändle, 'Does Direct Democracy Matter for Political Parties?', Party Politics 5/3 (1999), pp.283-302.

25. A. Lijphart, Democracy in Plural Societies (New Haven, CT: Yale University 1977), p.22; H.H. Kerr, 'The Swiss Party System: Steadfast and Changing', in H. Daalder (ed.), Party 
Systems in Denmark, Austria, Switzerland, the Netherlands, and Belgium (London: Frances Pinter 1987), pp.107-192 at 111.

26. E. Gruner and R. Hertig, Der Stimmbürger und die neue Politik (Bern: Haupt 1983), p.43.

27. In Switzerland the term 'militia' is not only used in a military sense but also refers to the fact that there are hardly any professional politicians, not even on national level.

28. Neidhart, 'Funktions- und Organisationsprobleme der schweizerischen Parteien'.

29. M. Duverger, Die politischen Parteien (Tübingen: J.C.B. Mohr Paul Siebeck 1959); S. Neumann (ed.), Modern Political Parties. Approaches to Comparative Politics (Chicago: University Press 1956); O. Kirchheimer, 'Der Wandel des westeuropäischen Parteiensystems', Politische Vierteljahresschrift 6/1(1965), pp.20-41; L.D. Epstein, Political Parties in Western Democracies (New York: Praeger 1967).

30. R.S. Katz and P. Mair, 'Three Faces of Party Organization. Adaption and Change', paper prepared for the XII World Congress of Sociology in Madrid (EPRU Working Papers 1990), p.5.

31. Kirchheimer, 'Der Wandel des westeuropäischen Parteiensystems'.

32. A. Panebianco, Political Parties: Organization and Power (Cambridge: Cambridge University Press 1988).

33. R.S. Katz and P. Mair, 'Changing Models of Party Organization and Party Democracy: The Emergence of the Cartel Party', Party Politics 1/1 (1995), pp.5-28.

34. Lipset and Rokkan, 'Cleavages Structures, Party Systems and Voter Alignments'.

35. Fagagnini, 'Die Rolle der Parteien auf kantonaler Ebene', p.91.

36. Kerr, 'The Swiss Party System', p.163.

37. P. Mair, 'Party Organizations: From Civil Society to the State', in R.S. Katz and P. Mair (eds.), How Parties Organize: Change and Adaption in Party Organizations in Western Democracies (London: Sage 1994), pp.1-22 at 5.

38. Ladner and Brändle, Fact-Sheets zum Wandel der Schweizer Parteien.

39. Fagagnini, 'Die Rolle der Parteien auf kantonaler Ebene', p.91.

40. R. Wiesli, 'Schweiz: Miliz-Mythos und unvollkommene Professionalisierung', in J. Borchert (ed.), Politik als Beruf: Die politische Klasse in westlichen Demokratien. ZENS - Europaund Nordamerikastudien 5 (Opladen: Leske + Budrich, i.E. 1999).

41. Gruner, Die Parteien der Schweiz, p.221.

42. Journal de Genève of 5 July, 1989.

43. Ladner and Brändle, Fact-Sheets zum Wandel der Schweizer Parteien.

44. H. Schmitt and S. Holmberg, 'Political Parties in Decline?', in H.-D. Klingemann and D. Fuchs (eds.), Citizens and the State (New York: Oxford University Press 1995), pp.95-133 at 212 .

45. Longchamp, Unterstützung von Bundesrat und Verwaltung, p.74.

46. Ibid., p.21; R. Nabholz, 'Das Wählerverhalten in der Schweiz: Stabilität oder Wandel? Eine Trendanalyse von 1971-1995', in H. Kriesi, W. Linder and U. Klöti (eds.), Schweizer Wahlen 1995. Ergebnisse der Wahlstudie Selects (Bern: Haupt 1998), pp.17-43.

47. Nabholz, 'Das Wählerverhalten in der Schweiz'.

48. E. Gruner, 'Eigentümlichkeiten der schweizerischen Parteienstruktur', Politische Vierteljahresschrift (July 1964), pp.203-17.

49. Gruner, Die Parteien der Schweiz, p.218.

50. Longchamp, Unterstützung von Bundesrat und Verwaltung, p.22.

51. R.S. Katz and P. Mair, 'The Membership of Political Parties in European Democracies 1960-1990', European Journal of Political Research 22 (1992), pp.329-45 at 334; P. Mair and I. van Biezen, 'Party Membership in Twenty European Democracies, 1980-2000', Party Politics (Jan. 2001), pp.5-23.

52. Ladner and Brändle, Fact-Sheets zum Wandel der Schweizer Parteien.

53. Kerr, 'The Swiss Party System', pp.156-7.

54. Hans Hirter, Wahlen 1999. Swiss Electoral Studies (Forschungsgemeinschaft der politikwissenschaftlichen Institute der Universitäten Bern, Genf und Zürich 2000), p.21.

55. Kerr, 'The Swiss Party System', pp.156-7.

56. Hirter, Wahlen 1999, p.21.

57. R.S. Katz and P. Mair, 'The Evolution of Party Organizations in Europe: The Three Faces of Party Organization', American Review of Politics 14 (Winter 1993), pp.593-617. 
58. Kirchheimer, 'Der Wandel des westeuropäischen Parteiensystems'.

59. G. Sani and G. Sartori, 'Polarization, Fragmentation and Competition in Western Democracies', in H. Daalder and P. Mair (eds.), Western European Party Systems: Continuity and Change (London: Sage 1983), p.322.

60. A. Ladner, 'Das Schweizer Parteiensystem und seine Parteien', in U. Klöti et al. (eds.), Handbuch der Schweizer Politik (Zürich: NZZ 1999), pp.213-60.

61. M. Brändle, 'Konkordanz gleich Konvergenz? Die Links-rechts-Positionierung der Schweizer Bundesratsparteien', Schweizerische Zeitschrift für Politikwissenschaft 5/1 (1999), pp.11-29.

62. Kirchheimer, 'Der Wandel des westeuropäischen Parteiensystems'.

63. Panebianco, Political Parties.

64. Katz and Mair, 'Changing Models of Party Organization and Party Democracy'.

65. Mair and van Biezen, 'Party Membership in Twenty European Democracies'. 